\title{
Programmed Cell Death Facilitates the Formation of Unisexual Male and Female Flowers in Persimmon (Diospyros kaki Thunb.)
}

\author{
Liyuan Wang ${ }^{1,2,+}$, Huawei Li ${ }^{1,+}$, Yujing Suo ${ }^{1}$, Weijuan Han ${ }^{1}$, Songfeng Diao ${ }^{1}$, Yini Mai ${ }^{1}$, \\ Peng Sun ${ }^{1, * \mathbb{D}}$, Fangdong $\mathrm{Li}^{1}$ and Jianmin $\mathrm{Fu}^{1, *}$ \\ 1 Key Laboratory of Non-timber Forest Germplasm Enhancement \& Utilization of State Administration of \\ Forestry and Grassland; Non-timber Forest Research and Development Center, Chinese Academy of \\ Forestry; National Innovation Alliance of Persimmon Industry, No. 3 Weiwu Road, Jinshui District, \\ Zhengzhou 450003, China; wangliyuan1120@163.com (L.W.); lihuaweiCAF@163.com (H.L.); \\ suoyj@caf.ac.cn (Y.S.); hanweijuan2013@163.com (W.H.); dsf@caf.ac.cn (S.D.); maiyini94@sina.com (Y.M.); \\ lifangdong66@163.com (F.L.) \\ 2 Research Institute of Forestry, Chinese Academy of Forestry, Beijing 100091, China \\ * Correspondence: sunpeng1017@126.com (P.S.); fjm371@163.com (J.F.); Tel.: +86-371-65996829 (P.S.); \\ Fax: +86-371-65953628 (P.S.) \\ + These authors contributed equally to this study.
}

Received: 10 December 2019; Accepted: 31 January 2020; Published: 5 February 2020

\begin{abstract}
Most varieties of persimmon (Diospyros kaki Thunb.) are gynoecious, while just a few are either monoecious, androgynomonoecious, or androecious. Persimmon flowers initially contain the original androecium and gynoecium followed by arrest of either pistil or stamen primordia before maturity. Abortion of inappropriate primordium in persimmon may be related to programmed cell death (PCD). To test this hypothesis, hematoxylin and eosin (H\&E) staining, terminal deoxynucleotidyl transferase-mediated dUTP nick-end labeling (TUNEL) assay, cyt-c immunohistochemistry (IHC) assay, transmission electron microscopy (TEM) observation, and real-time quantitative polymerase chain reaction (RT-qPCR) were used to clarify the occurrence and molecular regulatory mechanism of PCD in male and female floral buds during the 14 days prior to the second crucial morphological stage when inappropriate sexual primordia were arrested to form unisexual flowers. Accordingly, dead cells in inappropriate sex organs were largely accumulated during the microsporocyte and macrosporocyte period of male and female floral buds, respectively. This may explain the abortion of inappropriate sex organs, leading to unisexual flowers. PCD is necessary for normal growth and development in persimmons, as dead cells could also be observed in the normal flower organs. High levels of a gene homologous to $A M C 9$ may have accelerated the arrest of the pistil primordium during differentiation, leading to male unisexual flowers, and high levels of genes homologous to MeGI, $B A G 5$, AifA, and HSP70 in female floral buds were positively correlated with the arrest of stamen primordium. Future studies may try to transform unisexual flowers into hermaphroditic flowers by the regulation of PCD artificially, which will be helpful to the controlled pollination experiments.
\end{abstract}

Keywords: programmed cell death; Diospyros kaki; floral bud differentiation; unisexual flowers

\section{Introduction}

Persimmon (Diospyros kaki Thunb.) is one of the most important temperate fruit species in China and has been widely cultivated for more than 2000 years [1]. The quality of low-input-demanding and cold-resistant persimmon have received worldwide attention in recent years. Nevertheless, despite recent improvements, many difficulties remain to be resolved, such as the lower rate of cultivation of 
improved cultivars and the limited popularity of the fruits among consumers due to their astringency; thus, the large number of persimmon trees growing in China is an under-utilized resource [2]. Most persimmon cultivars are gynoecious, and just a few are monoecious or androgynomonoecious (such as 'Zenjimaru'). The rare androecious type is occasionally found in wild persimmon (D. kaki) populations [3,4]. Female (pistillate) flowers are usually solitary and male (staminate) flowers are organized in a three-flower cyme. The lack of male flowers strongly restricts controlled pollination of persimmon, which can be used to potentially produce new cultivars with better economic traits. Thus, research on sex differentiation of persimmon $(D . k a k i)$ to help control the sex type of flowers artificially has generated interest from the basic science community and economic stakeholders.

In D. lotus, the gender phenotype is decided by a pair of paralogous genes called OGI and MeGI. OGI, one Y-specific sex determinant gene, encodes a small RNA targeting the feminizing gene MeGI, which is located on the autosome. In hexaploid persimmon, the OGI is silenced by the presence of an insertion in the OGI promoter, and the DNA methylation level of the MeGI promoter determines the development of male or female flowers [5]. Nevertheless, the process of unisexual flower formation and the details of the regulatory mechanisms of persimmon sex differentiation requires further investigation. Our previous study divided the developmental processes of male and female persimmon flowers into 11 stages ranging from June (floral ontogeny) to May of the following year (blooming) (Figures 1 and 2; Table 1) [2,6]. Among which, the first crucial morphological stage for sex differentiation of persimmon was at stage 2 (mid-June) when the male flower formed a three-flower cyme primordium, while only the terminal floral primordium developed in the female floral bud, and the second crucial stage occurred at stage 8 (mid-April) when the stamen primordium in the female floral bud, and the pistil primordium in the male floral bud were arrested, which leads to the formation of unisexual flowers [6]. We presume that abortion of the inappropriate primordia may be related to programmed cell death (PCD) based on the findings of Li et al. (2016) [6].

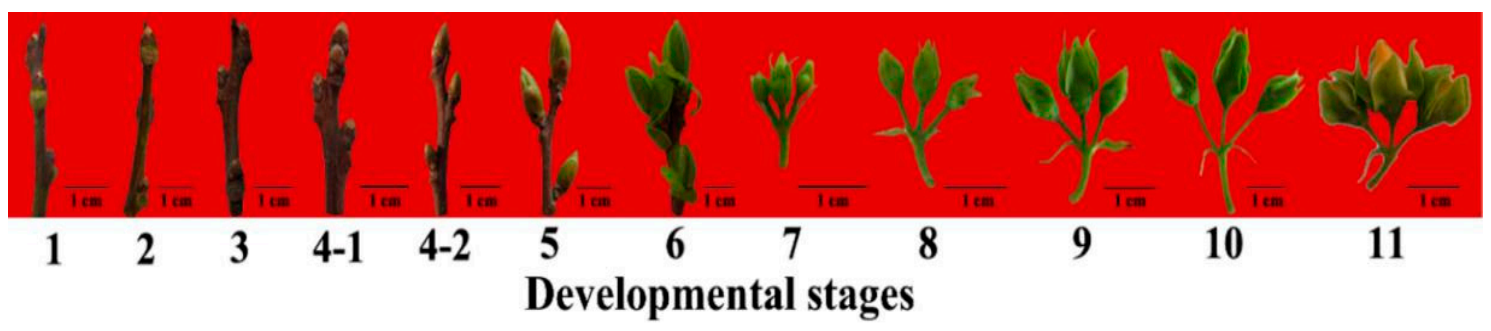

Figure 1. Male floral buds at different developmental stages (1-11).

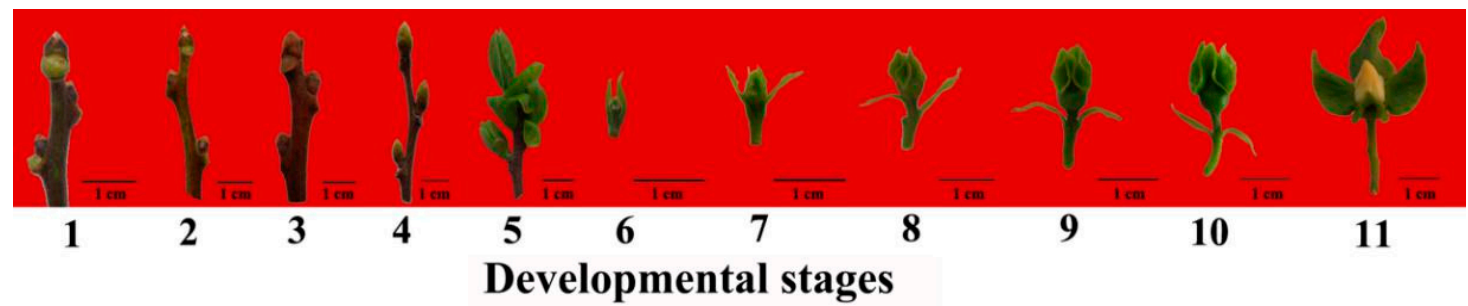

Figure 2. Female floral buds at different developmental stages (1-11). 
Table 1. Morphological descriptions and lengths of floral buds obtained from persimmon cultivar 'Zenjimaru' at the 11 developmental stages.

\begin{tabular}{|c|c|c|c|c|c|}
\hline Stage & Time & Sexuality & Morphological Description & Length of Floral Bud (cm) & Sample Figure \\
\hline \multirow{2}{*}{1} & June 3, 2014 & Male & \multirow{2}{*}{ Initiation of bract primordia } & 0.4 & Figure 1-1 \\
\hline & June 3, 2014 & Female & & 0.4 & Figure 2-1 \\
\hline \multirow[t]{2}{*}{2} & June 17, 2014 & Male & $\begin{array}{l}\text { Development of two lateral flower primordia; initiation of } \\
\text { inflorescence primordium of a three-flower cyme; differentiation of } \\
\text { four sepal primordia around the terminal flower }\end{array}$ & 0.5 & Figure 1-2 \\
\hline & June 17, 2014 & Female & $\begin{array}{c}\text { Arrest of two lateral flower primordia; initiation of inflorescence } \\
\text { primordium of solitary female flower; differentiation of four sepal } \\
\text { primordia around the terminal flower }\end{array}$ & 0.4 & Figure 2-2 \\
\hline \multirow{2}{*}{3} & March 3, 2015 & Male & \multirow{2}{*}{ Initiation of petal primordia } & 0.6 & Figure 1-3 \\
\hline & March 3, 2015 & Female & & 0.6 & Figure 2-3 \\
\hline \multirow{3}{*}{4} & March 19, 2015 & \multirow{2}{*}{ Male } & 4-1: Initiation of outside stamen primordia & 0.6 & Figure 1-4-1 \\
\hline & March 21, 2015 & & 4-2: Initiation of inner stamen primordia & 1.0 & Figure 1-4-2 \\
\hline & March 24, 2015 & Female & Initiation of one whorl of stamen primordia & 1.3 & Figure 2-4 \\
\hline \multirow{2}{*}{5} & March 28, 2015 & Male & \multirow[t]{2}{*}{ Initiation of carpel primordia } & 1.7 & Figure 1-5 \\
\hline & March 30, 2015 & Female & & 2.5 & Figure 2-5 \\
\hline \multirow{2}{*}{6} & April 1, 2015 & Male & Initiation of anther primordia; slight elongation of pistil primordia & 2.6 & Figure 1-6 \\
\hline & April 6, 2015 & Female & $\begin{array}{l}\text { Initiation of cylindrical pistil; stamen primordia showed no obvious } \\
\text { morphological change }\end{array}$ & 0.3 & Figure 2-6 \\
\hline \multirow[t]{2}{*}{7} & April 10, 2015 & Male & $\begin{array}{c}\text { Differentiation of filaments and locules in stamen; differentiation of } \\
\text { stigma and style was observed }\end{array}$ & 0.6 & Figure 1-7 \\
\hline & April 14, 2015 & Female & $\begin{array}{c}\text { Differentiation of nectary tissues and ovule primordia in pistil; } \\
\text { differentiation of filaments in stamen }\end{array}$ & 0.5 & Figure 2-7 \\
\hline \multirow[t]{2}{*}{8} & April 17, 2015 & Male & $\begin{array}{l}\text { Initiation of microsporocytes; arrest of carpel primordia indicated by } \\
\text { limited size increase }\end{array}$ & 0.8 & Figure 1-8 \\
\hline & April 17, 2015 & Female & $\begin{array}{l}\text { Initiation of two integuments and megasporocytes; arrest of outside } \\
\text { stamen primordia indicated by limited size increase }\end{array}$ & 0.8 & Figure 2-8 \\
\hline
\end{tabular}


Table 1. Cont.

\begin{tabular}{|c|c|c|c|c|c|}
\hline Stage & Time & Sexuality & Morphological Description & Length of Floral Bud (cm) & Sample Figure \\
\hline \multirow{2}{*}{9} & April 23, 2015 & Male & Appearance of tetrad period by meiosis of microsporocytes & 1.1 & Figure 1-9 \\
\hline & April 20, 2015 & Female & Appearance of tetrad period by meiosis of megasporocytes & 1.0 & Figure 2-9 \\
\hline \multirow{2}{*}{10} & April 25, 2015 & Male & Formation of uninuclear pollen & 1.3 & Figure 1-10 \\
\hline & April 23, 2015 & Female & Formation of uninuclear embryo sac & 1.3 & Figure 2-10 \\
\hline \multirow{2}{*}{11} & May 3, 2015 & Male & Formation of mature pollen & 1.3 & Figure 1-11 \\
\hline & May 3, 2015 & Female & Formation of mature embryo sac & 1.4 & Figure 2-11 \\
\hline
\end{tabular}


PCD, which is part of the normal life of a multicellular organism, is an active and orderly death process that can occur at various stages during development. Over the last two decades, much attention has been focused on PCD in animals and many discoveries have been made [7,8]. Meanwhile, cell proliferation, differentiation, and death occur continuously during plant growth and development, and many cells perform specific functions during different periods and in different environments. For instance, degeneration of the megaspore and microspore [9], death of the anther tapetum layer [10], and age-induced organ senescence [11] are developmental processes found in plants. Moreover, various abiotic stressors, such as heat, drought, or salt stress, can cause PCD, leading to a series of physiological and biomolecular changes or a defense response [12,13]. PCD in animals and plants redistributes nutrients [14], induces organogenesis [15], and is deemed to have a protective role [16]. In addition, PCD is an indispensable part of normal development of plants, particularly during sexual differentiation $[17,18]$, which has been linked to kiwifruit pollen fertility before using a terminal deoxynucleotidyl transferase-mediated dUTP nick-end labeling (TUNEL) assay [19]. Most unisexual flowers initially contain the original androecium and gynoecium followed by arrest of either the pistil or stamen primordia before maturity [20]. However, no study has documented the relationship between PCD and sex differentiation in persimmon.

We hypothesized that PCD would be closely associated with the arrest of inappropriate organs during sex differentiation. To test this hypothesis, hematoxylin and eosin (H\&E) staining, TUNEL assay, immunohistochemistry (IHC) assay, and transmission electron microscopy (TEM) observation were used to uncover the occurrence of PCD in male and female floral buds obtained from a persimmon cultivar 'Zenjimaru' (Diospyros kaki) from April 5 to 17, 2017 (Two weeks before the crucial second morphological stage, when the inappropriate sex organs have been arrested). In addition, we selected the crucial genes regulating persimmon sex differentiation based on transcriptome sequencing, some of which may be related to the regulation of PCD. Thus, the expression patterns of these genes were determined by real-time quantitative polymerase chain reaction (RT-qPCR) analysis to uncover the molecular regulatory mechanism of PCD and sex differentiation. This study improves our understanding of these processes and may be relevant for transforming unisexual flowers into the hermaphrodite type via artificial interference of PCD.

\section{Materials and Methods}

\subsection{Plant Materials}

Male and female floral buds were collected from three 10-year-old monoecious D. kaki 'Zenjimaru' in Yuanyang County, Henan Province, China ( $34^{\circ} 55^{\prime} 30^{\prime \prime}-34^{\circ} 56^{\prime} 45^{\prime \prime} \mathrm{N}, 113^{\circ} 46^{\prime} 24^{\prime \prime}-113^{\circ} 47^{\prime} 59^{\prime \prime}$ E). Approximately 20 male and female floral buds were randomly collected every 2 days from April 5, 2017 (carpel primordium and anther primordium at an early development stage just after their occurrence) to April 17, 2017 (when inappropriate sexual primordia were arrested to form unisexual flowers) [6]. After collection, half of the samples at various dates were fixed in FAA (formaldehyde: glacial acetic acid: $70 \%$ ethanol $=1: 1: 16, \mathrm{v} / \mathrm{v}$ ), and the others were quickly frozen in liquid nitrogen and stored at $-80^{\circ} \mathrm{C}$ until RNA extraction.

\subsection{Hematoxylin and Eosin (HEE) Staining}

The samples were fixed in FAA for $24 \mathrm{~h}$ and dehydrated in a graded ethanol series. Then, the plant materials were embedded in paraffin from $40^{\circ} \mathrm{C}$ to $60^{\circ} \mathrm{C}$ at a rate of increase of $3{ }^{\circ} \mathrm{C}$ every $15 \mathrm{~min}$, followed by laying in paraffin three times at $60^{\circ} \mathrm{C}$ each for $2 \mathrm{~h}$. Sections $(8-12 \mu \mathrm{m}$ thick) were sliced with a Leica RM2265 microtome (Leica, Nussloch, Germany), and then mounted on clean glass slides. The sections were deparaffinized and rehydrated in a graded xylol and ethanol series and stained with hematoxylin overnight. After being stained with $1 \%$ eosin for $20 \mathrm{~s}$, the sections dehydrated in a graded ethanol and xylol series. Finally, the microslides were dried and mounted with cover slips, and the stained sections were observed and photographed with a light microscope (Olympus, Tokyo, Japan). 


\subsection{Terminal Deoxynucleotidyl Transferase-Mediated dUTP Nick-End Labeling (TUNEL) Assay}

PCD was detected using a TUNEL assay kit (cat. no. 11684817910; Roche, Mannheim, Germany) in accordance with the manufacturer's protocol. Briefly, paraffin sections were washed twice with phosphate buffered saline (PBS; $\mathrm{pH}=7.4$ ) for $10 \mathrm{~min}$, then covered with proteinase $\mathrm{K}$ at $37^{\circ} \mathrm{C}$ for $30 \mathrm{~min}$. A sequencing solution was added to the tissues for $20 \mathrm{~min}$ at room temperature, and the paraffin sections were washed three times with PBS for 5 min each time. TdT and dUTP (ratio: 1:2) were added to the microslides. The paraffin-sectioned tissues were incubated under humid conditions for $1 \mathrm{~h}$ at $37^{\circ} \mathrm{C}$, while the positive control was treated with DNase prior to the TUNEL assay, and the negative control was just a dUTP solution. The tissues were stained with DAPI and kept in the dark for 10 min. Then, the microslides were washed and finally mounted with anti-fluorescence quenching sealant. The stained sections were observed and photographed with an inverted fluorescence microscope (Nikon, Tokyo, Japan) equipped with a digital camera (Nikon, Tokyo, Japan).

\subsection{Immunohistochemistry (IHC) Assay}

Paraffin sections were used to detect the expression of cyt-c using cyt-c antibody at a 1:2000 dilution. Briefly, all sections were pretreated with citrate buffer $(\mathrm{pH}=6.0)$ in a microwave oven, then washed three times in PBS. The sections were placed in a 3\% hydrogen peroxide solution in the dark for $25 \mathrm{~min}$ to block endogenous peroxidase, and then incubated in $3 \%$ bovine serum albumin solution for $30 \mathrm{~min}$ at room temperature and incubated with primary antibodies overnight at $4{ }^{\circ} \mathrm{C}$ under humid conditions, while the negative control was incubated in PBS. After washing, the paraffin sections were incubated with secondary antibody for $50 \mathrm{~min}$ at room temperature. The paraffin sections were washed three times in PBS for $5 \mathrm{~min}$ each and then incubated in a diaminobenzidine solution. Thereafter, the slides were counterstained with hematoxylin for $3 \mathrm{~min}$ followed by incubation in a graded xylol and ethanol series. The slides were cover-slipped, and stained tissues were observed and photographed with a light microscope (COIC, Chongqing, China).

\subsection{Transmission Electron Microscopy (TEM) Observation}

Floral buds on April 14, 2017 were collected and fixed for $2 \mathrm{~h}$ at room temperature in electron microscope fixative (Servicebio, Wuhan, China). After three washes with phosphate buffer (PB; $\mathrm{pH}=7.4$ ) for $15 \mathrm{~min}$ each, samples were post-fixed for $5 \mathrm{~h}$ at room temperature in $1 \% \mathrm{O}_{\mathrm{s}} \mathrm{O}_{4}$ prepared in PBS. Fixed samples were washed three times with PBS, dehydrated in a graded acetone and ethanol series for $1 \mathrm{~h}$ each, and embedded in epoxy resin embedding medium. Ultrathin sections $(60-80 \mathrm{~nm})$ of stamen and carpel were then prepared using an ultramicrotome (Leica, Nussloch, Germany), stained with uranyl acetate and lead citrate for $15 \mathrm{~min}$ each. Finally, the samples were dried overnight, and the stained sections were observed and photographed with a transmission electron microscope (Hitachi, Tokyo, Japan).

\subsection{Real-Time Quantitative Polymerase Chain Reaction}

We have compared the transcriptome sequences between male and female floral buds obtained on April 13, 2016 from a same 'Zenjimaru' tree, the raw short reads were available in the NCBI SRA database under the accession number: SRP151715. According to which [21], eight genes significantly different expressed between male and female floral buds and related to the regulation of PCD were selected to determine the expression pattern during the period from April 5 to 17, 2017 in this study. These genes were male growth inhibitor gene in Diospyros (MeGI), BAG family molecular chaperone regulator 5 (BAG5), apoptosis-inducing factor homolog A (AifA), heat shock protein 70 (HSP70), metacaspase-9 (AMC9), cell division control protein 2 homolog (CDC2), Diospyros digyna MADS-domain transcription factor (GLO), and agamous like 1 (AGL1). Among which, MeGI is specific in Diospyros, BAG5 is a stress-inducible gene, AifA, HSP70, AMC9, and CDC2 are genes involving the formation of PCD in plants, GLO is a MADS-box family gene regulating flower organ development, and AGL1 promotes the formation of 
gynoecium (Table 2). Specific primers that corresponded to the conserved region of each gene were designed in the sequenced database (Table 3).

Table 2. Fold-changes and descriptions of genes in male vs female floral buds based on transcriptome sequences of persimmons.

\begin{tabular}{ccccc}
\hline Gene ID & Log $_{2}$ FC & P adj & Homologous Gene & Gene Function \\
\hline c100711_g1 & -1.7395 & $1.48 \times 10^{-40}$ & MeGI & Male growth inhibitor gene in Diospyros \\
[5]
\end{tabular}

Programmed cell death (PCD).

Table 3. Sequences of primers used to study programmed cell death (PCD)-related genes.

\begin{tabular}{|c|c|c|c|}
\hline $\begin{array}{c}\text { Gene ID } \\
\text { (Homologous Gene) }\end{array}$ & Forward Primer Sequence $\left(5^{\prime}-3^{\prime}\right)$ & Reverse Primer Sequence $\left(5^{\prime}-3^{\prime}\right)$ & Product Size (bp) \\
\hline GAPDH (reference gene) & AGCTCTTCCACСТCTCCAGT & TGCTAGCTGCACAACCAACT & 157 \\
\hline MeGI (c100711_g1) & GGAGTTGAACTTTGGGAACG & AAGGCGACACTTGTGGACGA & 199 \\
\hline BAG5 (c115962_g1) & GATACCTGTTCGCTTCGT & TCAACCGCCTCAACCTCT & 138 \\
\hline AifA (c86489_g1) & GTAACCTTTCACCCTCAA & CTATCAGAGCCGATTGTAT & 137 \\
\hline HSP70 (c104934_g1) & TTTTATGCGACGATTACCA & GCAATAGCTGCTGCACTTT & 175 \\
\hline AMC9 (c109216_g1) & СTGCTCCTTCTCCTTGTCTATG & GTGGACTTCCGTCAACTGG & 105 \\
\hline CDC2 (c115753_g1) & TGGCTGACTTTGGATTGG & ATGGCAGACGAGTATTGGTG & 124 \\
\hline GLO (c73805_g1) & TCATTGCTCAGGTTCTCA & AATACTGTAGCCCTTCCA & 103 \\
\hline AGL1 (c117647_g3) & CGCCTTTATGAATACGCC & ТСТССААТСТТСССТССА & 241 \\
\hline
\end{tabular}

Total RNA was isolated from the organs using EZ-10 DNAaway RNA Miniprep Kits (Sangon Biotechnology Co., Shanghai, China) according to the manufacturer's instructions. First-strand cDNA was synthesized with a TRUEscript 1st Strand cDNA Synthesis Kit (Kemix, Beijing, China) and the RT-qPCR assays were performed with SYBR Green Dye (Kemix) using a Bio-Rad CFX96 RT-PCR platform (Bio-Rad Laboratories, Hercules, CA, USA) with the following cycle conditions: $94{ }^{\circ} \mathrm{C}$ for $2 \mathrm{~min}$, followed by 40 cycles of $94{ }^{\circ} \mathrm{C}$ for $20 \mathrm{~s}, 55^{\circ} \mathrm{C}$ for $20 \mathrm{~s}$, and $72{ }^{\circ} \mathrm{C}$ for $30 \mathrm{~s}$. For each measurement, independent standard curves were constructed and three replications of mixed male/female samples at five time points were analyzed. The mean $\mathrm{Ct}$ of three replications was used. The $2^{-\Delta \Delta \mathrm{Ct}}$ method was applied to calculate the RNA transcript fold-changes, and GAPDH served as the internal control.

\subsection{Statistical Analysis}

Statistical analyses were performed using SPSS Statistics 20.0 for Windows software (SPSS, Inc., Chicago, IL, USA). The expression levels of the genes in the male and female floral buds at different developmental stages were analyzed by one-way analysis of variance (ANOVA). If differences among 
developmental stages were detected, Tukey's multiple comparison test was applied to compare the means. A significance level of $P<0.05$ was used for the analyses. Because the main point of interest was the difference between male and female floral buds at each stage, we measured the difference in gene levels between male and female floral buds at each developmental stage using an independent sample test. A significance level of $P<0.05$ was used for the analyses.

\section{Results}

\subsection{Hematoxylin and eosin (HEE) Assay}

Carpel was observed in male floral buds collected in early April with an increase in air temperature, which was called the carpel primordium differentiation phase (Figure 3a; samples collected on April 5, 2017). After all male organs appeared, anthers emerged from the apical meristem of the stamen primordium, and the carpel primordium elongated slightly (Figure 3b; samples collected on April 8 , 2017). After the anther primordium appeared, the stamen primordium developed further at the base, which formed the filament and pollen sac, while the carpel primordium continued to develop (Figure 3c; samples collected on April 11, 2017). Numerous microsporocytes with rich cytoplasm developed from the anther sporogonium, but the carpel primordium presented conspicuous changes closely related to PCD (cytoplasm shrinkage, chromatin condensation, and karyorrhexis) (Figure 3d,e; samples collected on April 14, 2017). The microsporocyte continued growth, and the pollen grains matured gradually, while the carpel primordium had already been arrested and aborted (Figure 3f; samples collected on April 17, 2017).

The carpel in female floral buds were identifiable in early April with an increase in air temperature, which was called the carpel primordium differentiation phase (Figure 4a; samples collected on April 5, 2017). Subsequent to differentiation of the carpel primordium, the carpel primordium elongated, whereas the stamen primordium was slightly changed (Figure 4b; samples collected on April 8, 2017). The ovule at the base of the carpel primordium formed without maturing, whereas the upper part differentiated into the style and stigma during the ovule primordial period. The stamen primordium gradually elongated and became a little thin (Figure 4c; samples collected on April 11, 2017). The ovule primordium gradually elongated and grew downwards, the front part developed into the nucellus with macrosporocyte, while the other parts developed into the funicle (Figure $4 \mathrm{~d}$; samples collected on April 14, 2017). At the same time, the stamen primordium formed anthers and weak filaments, displaying condensation of chromatin and loss of the nucleoli (Figure 4e; samples collected on April 14, 2017). Subsequently, female flowers became structurally visible, while the stamen primordium was arrested and aborted into staminode (Figure 4f; samples collected on April 17, 2017). 


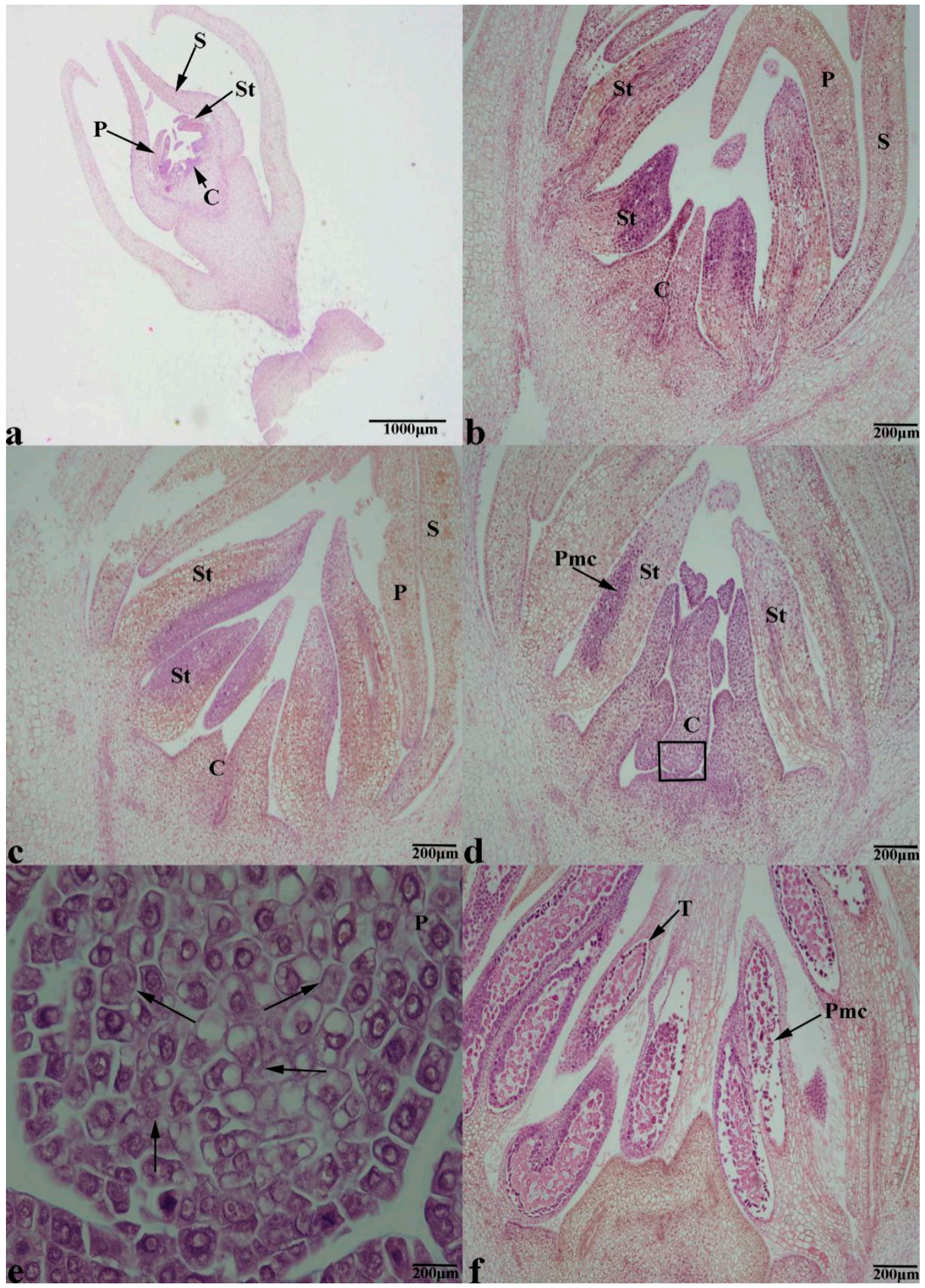

Figure 3. Hematoxylin and eosin (H\&E) staining of male floral buds during differentiation in persimmon. (a) Sample at the carpel primordium differentiation stage harvested on April 5, 2017. (b) Sample at the anther primordium differentiation stage harvested on April 8, 2017. (c) Details of the pollen sac and filaments harvested on April 11, 2017. (d) Details of the microsporocyte harvested on April 14, 2017. (e) Carpel from the rectangle magnified in (d) (arrows indicate dead cells). (f) Details of the male floral bud harvested on April 17, 2017. ( $\mathrm{C}=$ carpel; $\mathrm{P}=$ petal; $\mathrm{Pmc}=$ pollen mother cell; $\mathrm{S}=$ sepal; St $=$ stamen; $\mathrm{T}=$ tapetum). 


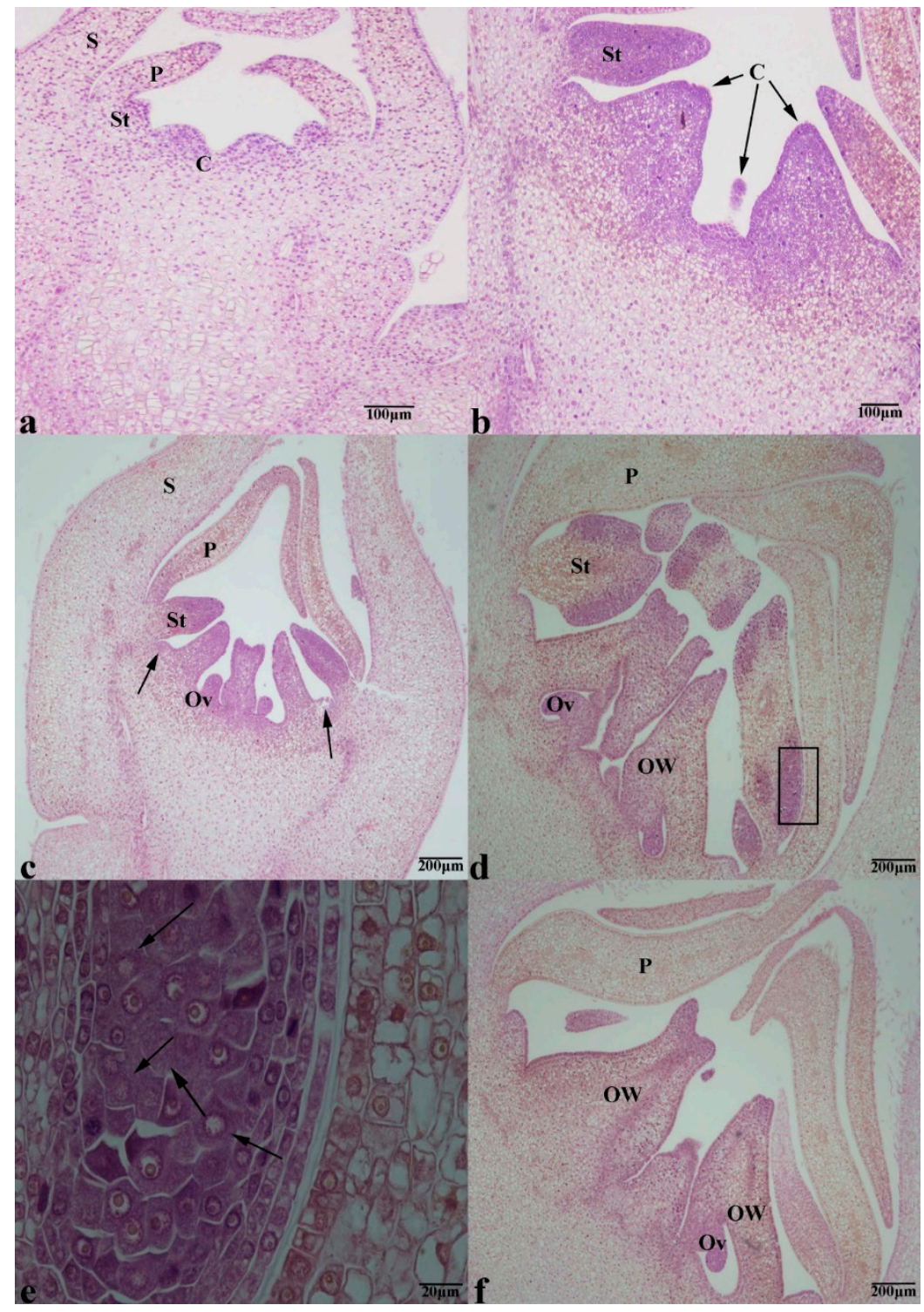

Figure 4. H\&E staining of female floral buds during differentiation in persimmon. (a) Details of the carpel primordium harvested on April 5, 2017. (b) Further differentiation of the carpel primordium harvested on April 8, 2017. (c) Sample at the ovule primordium differentiation stage (arrows indicate nectary tissues) harvested on April 11, 2017. (d) Details of the integuments and macrosporocyte harvested on April 14, 2017. (e) Image of the stamen from the rectangle magnified in (d) (arrows indicate dead cells). (f) Details of the female floral bud harvested on April 17, 2017. (C = carpel; $\mathrm{Ov}=$ ovule; $\mathrm{OW}=$ ovary wall; $\mathrm{P}=$ petal; $\mathrm{S}=$ sepal; $\mathrm{St}=$ stamen).

\subsection{TUNEL Assay}

Although stained-dead cells were present during the carpel primordium differentiation stage (Figure 5a; samples collected on April 5, 2017) and the anther primordium differentiation stage (Figure 5b; samples collected on April 8, 2017) of male floral buds, the pistil primordium grew normally. Sections from Figure $5 c$ exhibited a substantially higher proportion of dead cells in the pistil primordium than the first two stages, and positive staining of dead carpel cells were represented by a green color, while blue-stained were non-PCD (Figure 5d; samples collected on April 11, 2017). Green staining was also observed from the microsporocyte stage of April 14, 2017, the pistil primordium showed a stronger positive staining reaction and more signs of dead cell changes in the region comparable to 
the previous stage (Figure 5e). The anther primordium was visible to the naked eye at the stage of April 17, 2017, whereas the dead cells of the pistil primordium were almost invisible (Figure 5f).

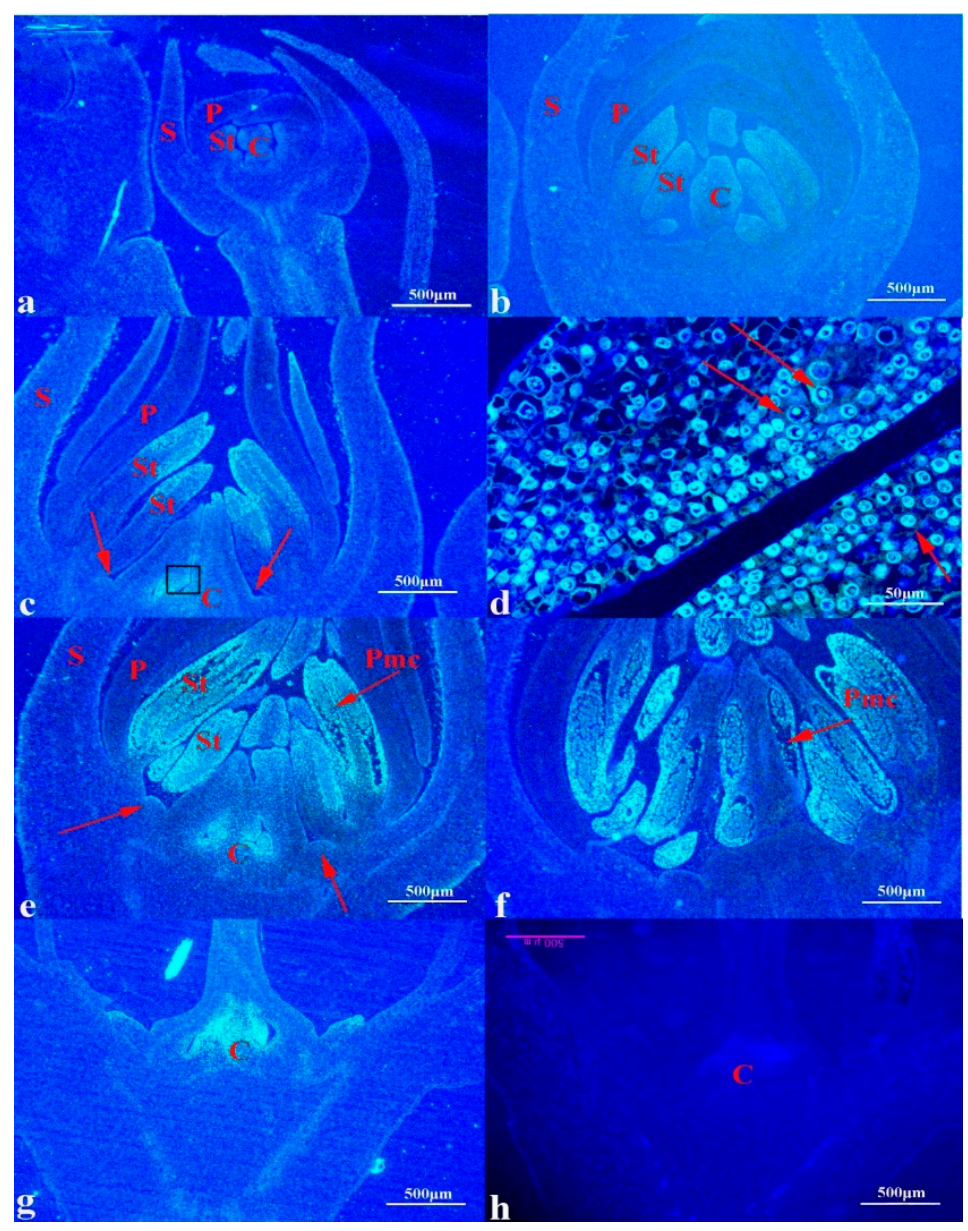

Figure 5. Terminal deoxynucleotidyl transferase-mediated dUTP nick-end labeling (TUNEL) staining of male floral buds during differentiation in persimmon. (a,b) Pistil-specific DNA damage became detectable at the carpel primordium differentiation stage in plants harvested on April 5, 2017 and at the anther primordium differentiation stage in plants harvested on April 8, 2017. (c) Dead cells reached a height in the carpel primordium in plants harvested on April 11, 2017. (d) Image of the carpel from the rectangle magnified in (c) (arrows indicate dead cells). (e) Pistil primordium harvested on April 14, 2017 at the microsporocyte stage showed strong positive staining and signs of PCD changes. (f) The dead cells of pistil primordium harvested on April 17, 2017 were almost invisible. (g) Positive control of the pistil primordium in male flower buds harvested on April 11,2017, where nuclei were evenly stained after DNase treatment prior to the TUNEL assay. (h) Negative control of the pistil primordium in male flower bud harvested on April 11, 2017, where no observable TUNEL signals were observed. (C = carpel; $\mathrm{P}=$ petal; $\mathrm{Pmc}=$ pollen mother cell; $\mathrm{S}=$ sepal; $\mathrm{St}=$ stamen $)$.

As shown in Figure 6, there were no distinguishable differences between the carpel primordium differentiation stage (Figure 6a,b; samples collected on April 5 and 8,2017) and the ovule primordium differentiation stage (Figure 6c; samples collected on April 11, 2017) of female floral bud in terms of the areas of dead cells in the stamen primordium. However, the sections of the samples collected on April 14, 2017 showed more dead cells in the stamen primordium than the stages described above (Figure 6d). The arrows in Figure 6e pointed to strong positive staining for dead cells of the stamen primordium based on the green-colored nuclei. Although stained dead cells remained detectable at the stage of April 17, 2017, the stamen primordium had already aborted (Figure 6f). 


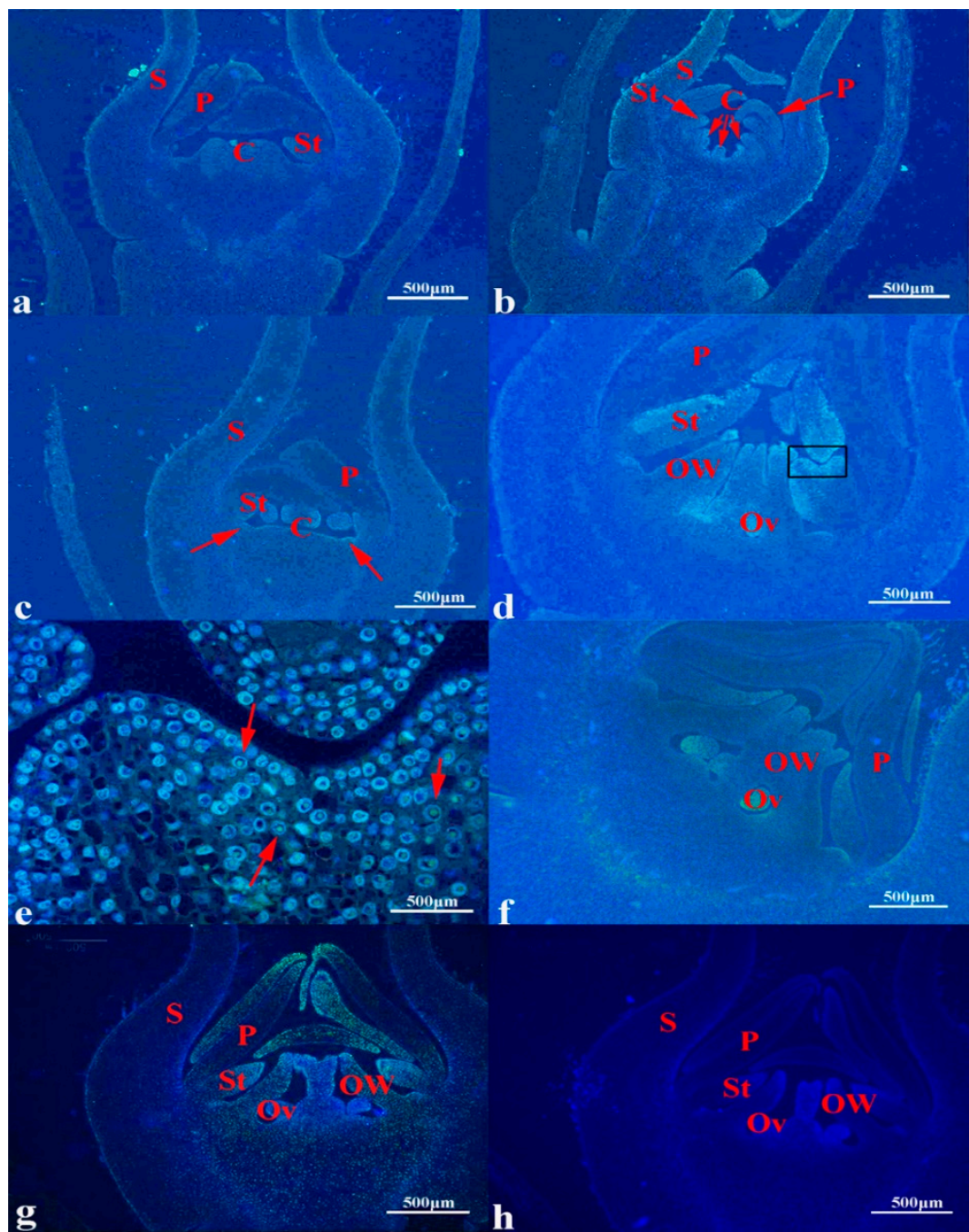

Figure 6. TUNEL staining of female floral buds during differentiation in persimmon. $(\mathbf{a}, \mathbf{b})$ The carpel primordium differentiation stage harvested on April 5, 2017 and April 8, 2017 showed that there was no observable DNA damage in the stamen primordium of female floral buds. (c) April 11, 2017 was defined as the ovule primordium differentiation stage, when the levels of dead cells in the stamen primordium equaled those of the carpel primordium differentiation stage (arrows indicate nectary tissues). (d) Strong positive staining for dead cells of the stamen primordium based on green color was clearly observed at the internal and external integument and macrosporocyte stage harvested on April 14, 2017. (e) Image of the stamen from the rectangle magnified in (d) (arrows indicate dead cells). (f) The dead cells of the stamen primordium in tissues harvested on April 17, 2017 were almost invisible. (g) Positive control for the female flower bud harvested on April 14, 2017 showing nuclei evenly stained in the stamen primordium after DNase treatment prior to the TUNEL assay. (h) Negative control for the female flower bud harvested on April 14, 2017, where no TUNEL signals were observed in the stamen primordium. $(\mathrm{C}=$ carpel; $\mathrm{Ov}=$ ovule; $\mathrm{OW}=$ ovary wall; $\mathrm{P}=$ petal; $\mathrm{S}=$ sepal; $\mathrm{St}=$ stamen $)$.

\subsection{IHC Assay}

A substantial increase in immunoreactive expression for cyt-c was observed, with a brown-labeled cytoplasm and nucleus in the pistil primordium during the early phase of male floral bud differentiation (Figure 7a-c; samples collected on April 5-11, 2017). Indeed, the level of PCD markers (active cyt-c) in the pistil primordium reached a peak at the microsporocyte stage of April 14, 2017 with several focal sites of greatest expression (Figure 7d). Prominent cyt-c expression was visible in Figure 7e with noticeable brown-stained cytoplasm and chromatin, indicating remarkable subsets of dead cells in the 
pistil. Positive immunoreactions were present in the pistil primordium cells at the stage of April 17, 2017, but fewer than the stages described above (Figure 7f).

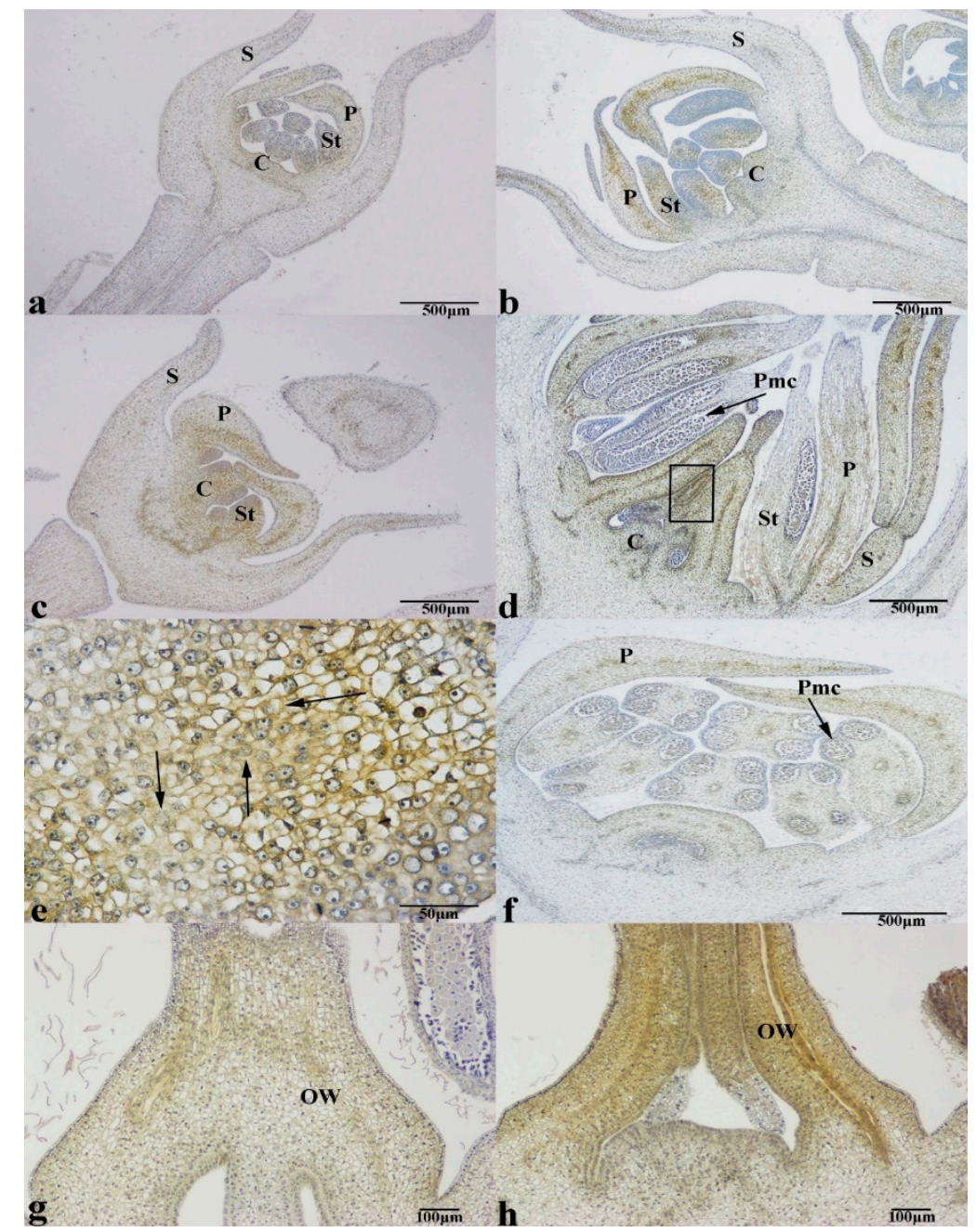

Figure 7. Cyt-c immunohistochemical (IHC) expression of male floral buds during differentiation in persimmon. (a-c) Immunostaining of cyt-c as brown staining in the pistil primordium at the carpel primordium differentiation stage in tissues harvested on April 5, 2017, the anther primordium differentiation stage in tissues harvested on April 8, 2017, and the pollen sacs and filaments stage harvested on April 11, 2017 increased gradually. (d) The highest expression of active cyt-c was detectable at the microsporocyte stage in the pistil primordium in tissues harvested on April 14, 2017. (e) Image of the pistil primordium from the rectangle magnified in (d) (arrows indicate dead cells with brown-labeled cytoplasm and nucleus). (f) Regardless of the presence of PCD in tissues harvested on April 17, 2017, the pistil primordium had already been aborted. (g) Negative control for the pistil primordium in male flower buds harvested on April 14, 2017, where no distinct immunohistochemical (IHC) staining of cyt-c was detected in the pistil primordium. (h) Pistil primordium in male flower buds harvested on April 14, 2017. Dead cells were stained brown $(\mathrm{C}=$ carpel; $\mathrm{P}=$ petal; $\mathrm{Pmc}=$ pollen mother cell; $\mathrm{S}=$ sepal; $\mathrm{St}=$ stamen).

The results showed no cell damage in the stamen primordium of female flower buds in our sections at the carpel primordium differentiation stage (Figure 8a; samples collected on April 5, 2017). Plant cell death appeared in the stamen primordium with very occasional weak nuclear and cytoplasmic foci expressing cyt-c (Figure 8b; samples collected on April 8, 2017). The stamen primordium in tissues harvested on April 11, 2017 in Figure 8c exhibited positively cyt-c immunostaining in the cytoplasm and nucleus. The strongest cytoplasmic cyt-c expression emerged in the stamen primordium at the internal 
and external integument and macrosporocyte stage in tissues harvested on April 14, 2017, confirming that this was the critical time for the arrest of the male organs in female flowers (Figure $8 \mathrm{~d}$,e). Weak positive IHC signals for cyt-c protein were detected in cells originating from the stamen primordium at the stage of April 17, 2017 (Figure 8f).

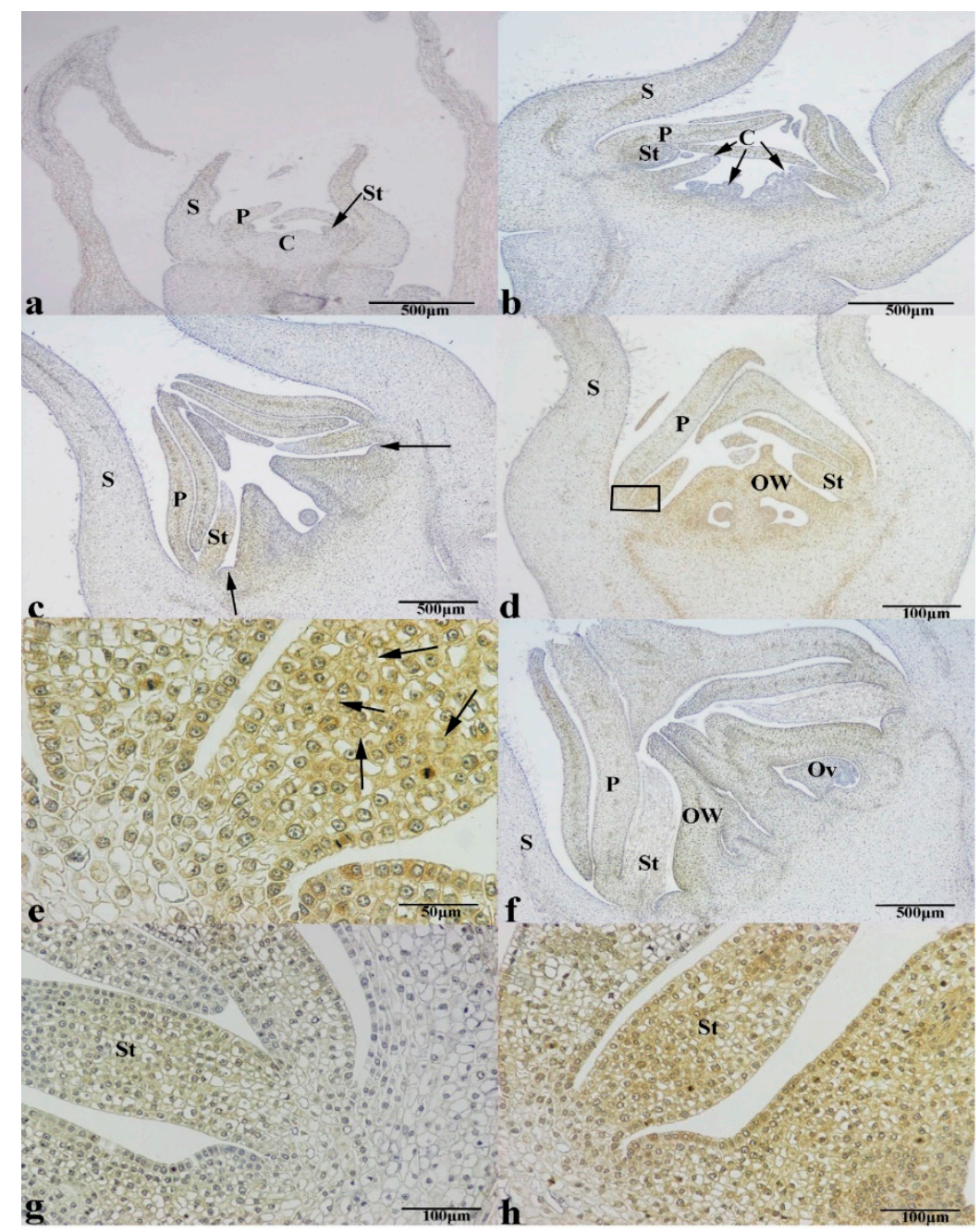

Figure 8. Cyt-c IHC expression of female floral buds during differentiation in persimmon. (a) No distinct cyt-c protein expression was observed during the carpel primordium differentiation stage in tissues harvested on April 5, 2017. (b) Weak cyt-c brown-staining signals occurred in the stamen primordium at the carpel primordium differentiation stage in tissues harvested on April 8, 2017. (c) Expression of the cyt-c protein at the ovule primordium differentiation stage (arrows indicate nectary tissues) in the stamen primordium harvested on April 11, 2017 was significantly greater. (d) Strong staining signals were clearly distinguishable in the stamen primordium in tissues harvested on April 14, 2017. (e) Image of the stamen primordium from the rectangle magnified in (d) (arrows indicate brown-stained dead cells). (f) Weak positive IHC signals for cyt-c expression were observed in tissues harvested on April 17, 2017. (g) Negative control of the stamen primordium in female flower buds harvested on April 14, 2017, where no distinct cyt-c staining signals was detected. (h) Stamen primordium in female flower buds harvested on April 14, 2017 ( $\mathrm{C}=$ carpel; $\mathrm{Ov}=$ ovule; $\mathrm{OW}=$ ovary wall; $\mathrm{P}=$ petal; $\mathrm{S}=$ sepal; $\mathrm{St}=$ stamen).

\subsection{TEM Observation}

To further confirm the occurrence of dead cells in inappropriate sex organs, we compared the ultrastructures of cells in carpel and stamen from both male and female floral buds collected on April 14, 
2017. Ultrastructural observation of the cells in the stamen from male flowers reveals the normal development of cell nucleus, cytoplasm, and vacuole (Figure 9a), whereas the presence of flocculated cytoplasm condensation (showed by arrow I), nucleoli segmentation (showed by arrow II), and in some examples, engulfment of the cytoplasm by lytic vacuoles (showed by arrow III), were evident in the cells from the arrested carpel (Figure 9b).
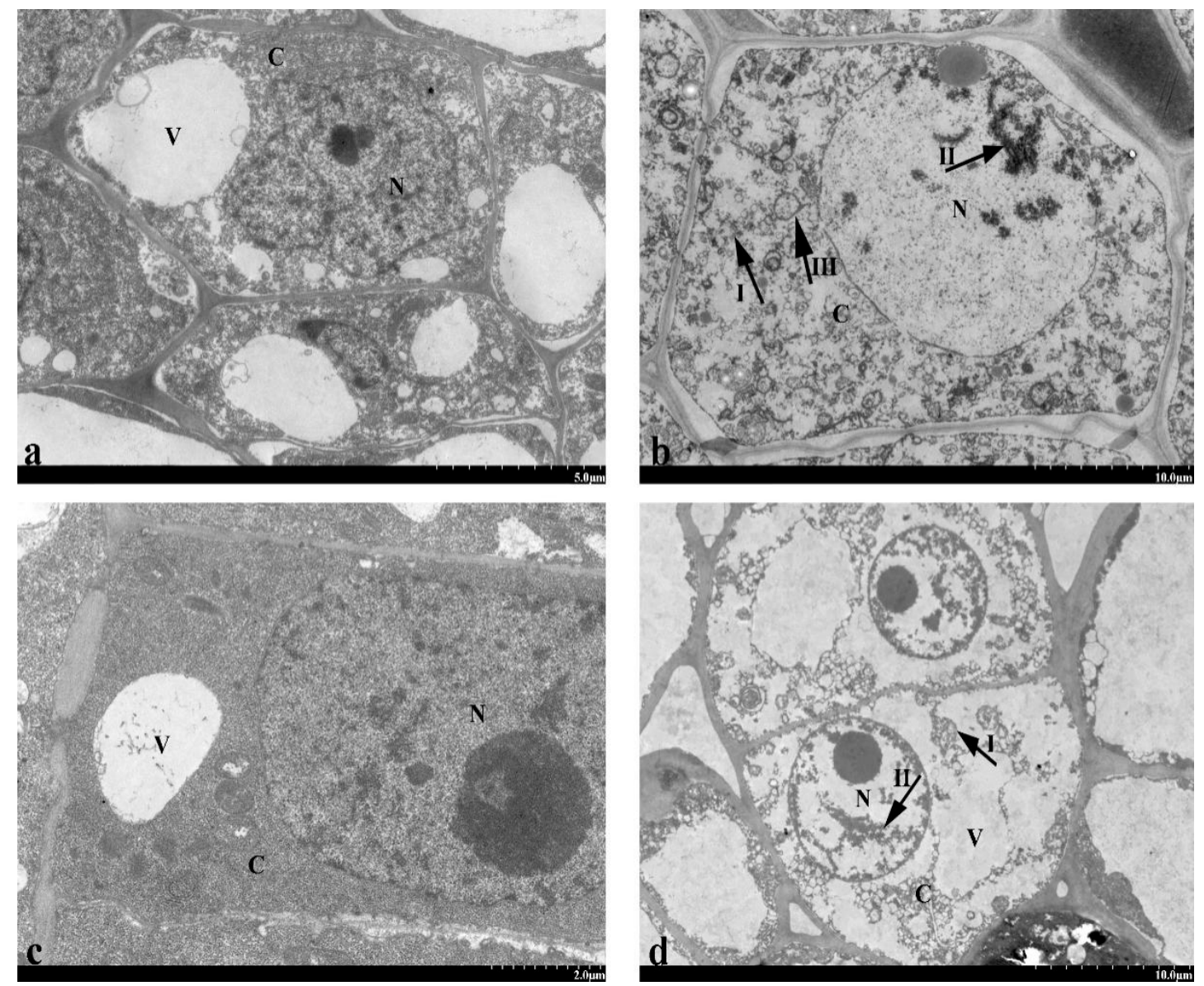

Figure 9. Cells of carpel and stamen in both male and female floral buds collected on April 14, 2017 at the ultrastructural level. (a) Normal developmental cells of the stamen in male flowers. (b) The cells in the arrested carpel from male flowers showed condensation of cytoplasm (showed by arrow I), fragmentation of nucleoli (showed by arrow II), and engulfment of the cytoplasm by vacuoles (showed by arrow III). (c) Normal developmental cells of the carpel in female flowers. (d) The cellular contents in the cells of the arrested stamen with shrinkaged cytoplasm and chromatin (showed by arrow II and II, respectively) in female flowers were degenerated ( $\mathrm{N}=$ nucleus; $\mathrm{V}=$ vacuole; $\mathrm{C}=$ cytoplasm).

Figure $9 \mathrm{c}$ shows that the carpel in female flowers was in a normal developmental condition with functional organelles (cell nucleus, cytoplasm, and vacuole), while the cellular contents in the arrested stamen were degenerated, and the cytoplasm as well as chromatin were shrinkaged (showed by arrows I and II) (Figure 9d). Other morphological events in the cells from the arrested stamen, including decrease in the volume of the cytoplasm and increase in the volume of vacuole, were also observed (Figure 9d).

\subsection{Abortion of Male Floral Organs}

The relative expression of gene c100711_g1, homologous to MeGI, generally declined in male floral buds, except for a slight increase on April 11, 2017, with a level approximately $96.4 \%$ of that on April 5, 2017. However, a continuous increase in female flower buds exhibited from April 8 to 14, 2017, which 
resulted in the gene c100711_g1 expression level on April 14, 2017 that was dozens of times higher than that on April 5, 2017 (Figure 10a). A slight change in the gene c115962_g1, homologous to BAG5, was detected from April 5 to 17, 2017 in male flower buds, but it was not particularly noticeable. Peak c115962_g1 expression in the female flower buds occurred on April 14, 2017, which was a 17.0-fold increase above the other stages. Then, it was downregulated on April 17, 2017 and showed a similar expression level to that observed at the initial stage on April 5, 2017 (Figure 10b). The RT-qPCR relative expression pattern for gene c86489_g1, homologous to AifA, shown in the male floral buds was comparable to that in the female buds, except that the gene c86489_g1 levels in the female floral buds increased and decreased more sharply than those in the male floral buds (Figure 10c). There was a sharp increase in the gene c104934_g1, homologous to HSP70, in male floral buds from April 11 to 17, 2017, which resulted in a relative two-fold greater gene expression on April 17, 2017 than that on April 11, 2017. The gene in the female floral buds increased approximately 58.5 times on April 14, 2017 from that on April 5, 2017, then declined sharply on April 17, 2017 (Figure 10d).
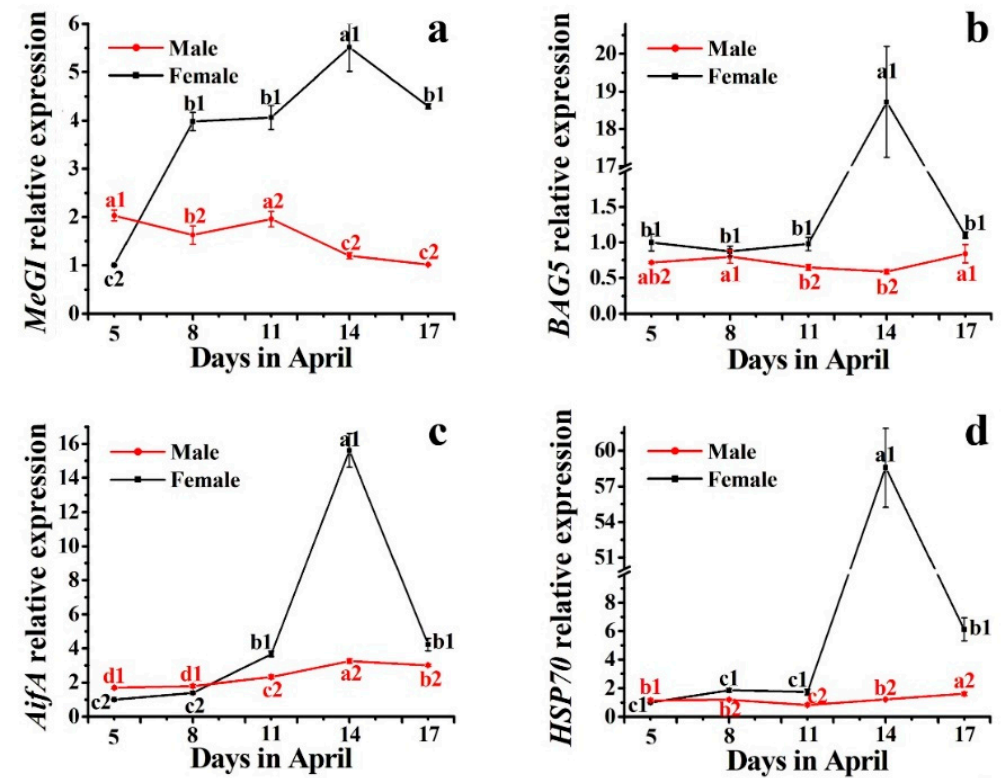

Figure 10. RT-qPCR analysis of the expression levels of PCD-related genes correlated with male floral organs during different developmental stages. (a-d) represent the relative expression levels of the genes homologous to MeGI, BAG5, AifA, and HSP70. The value on April 5, 2017 in female floral buds was set to 1.0. Data are expressed as the mean \pm standard error of three replications. Red and black letters indicate a significant difference among developmental stages for male and female floral buds, respectively, based on Tukey's multiple comparison test at the $P<0.05$ significance level. Different numbers indicate a significant difference between male and female flowers at each developmental stage based on an independent $T$-test at the $P<0.05$ significance level.

Taken together, the genes homologous to MeGI, BAG5, AifA, and HSP70 in female floral buds were remarkably higher than those in male floral buds from April 8 to 17, 2017, particularly during the crucial stage on April 14, 2017 (approximately 4.6-, 31.8-, 4.8-, and 48.1-fold of the expression levels of the genes homologous to MeGI, BAG5, AifA, and HSP70 in female floral buds than those in male floral buds, respectively), suggesting that relatively high levels of these genes might be closely correlated with arrest of male primordium during differentiation of female floral buds.

\subsection{Abortion of Female Floral Organs}

The gene c109216_g1, homologous to AMC9, in male floral buds was enhanced from April 11 to 14, 2017, and then decreased, which resulted in the highest relative expression on April 14, 2017 compared with the other sampling dates. Expression of the gene c109216_g1 in the female floral buds 
increased from April 5 to 8, 2017 and was sharply downregulated from April 8 to 17, 2017, resulting in relative gene expression on April 17, 2017 that was approximately 1.1 times greater than that on April 5, 2017. Briefly, the gene c109216_g1 levels in the female floral buds on April 5, 14, and 17, 2017 were approximately $52.2,30.4$, and $38.5 \%$, respectively, of those in male flowers. It is likely that the arrest of pistil primordium during differentiation resulted from upregulation of the gene homologous to AMC9 during the April 14, 2017 critical period (Figure 11a).
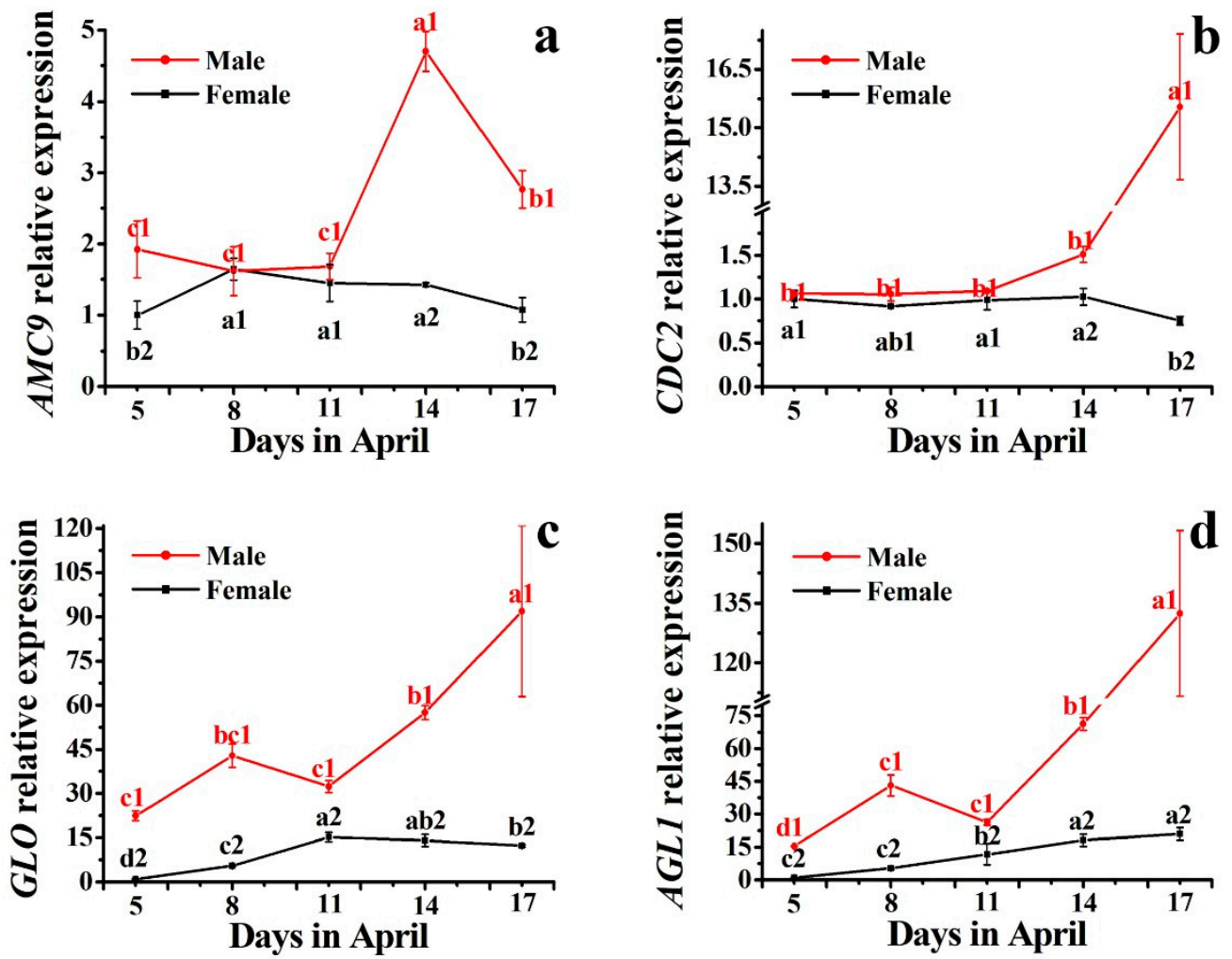

Figure 11. RT-qPCR analysis of the expression levels of PCD-related genes correlated with female floral organs during different developmental stages. (a-d) represent the relative expression levels of the genes homologous to AMC9, CDC2, GLO, and AGL1. The value on April 5, 2017 in female floral buds was set to 1.0. Data are expressed as the mean \pm standard error of three replications. Red and black letters indicate a significant difference among developmental stages for male and female floral buds, respectively, based on Tukey's multiple comparison test at the $P<0.05$ significance level. Different numbers indicate a significant difference between male and female flowers at each developmental stage based on an independent $T$-test at the $P<0.05$ significance level.

Strikingly, a similar discernible pattern of the genes homologous to CDC2, GLO, and AGL1 was found in male floral buds, for these genes increased markedly from April 5 to 17, 2017, except for a slight decline of the genes homologous to GLO and AGL1 on April 11, 2017, leading to a peak on April 17, 2017 that was approximately 14.5, 4.0, and 8.5 times as much as that on April 5, 2017, respectively. Moreover, the genes homologous to $C D C 2, G L O$, and AGL1 in male floral buds among all the stages were significantly higher than that in female floral buds, particularly on April 17, 2017, when there were approximately 20.6-, 7.2-, and 6.3-fold higher expression levels in male floral buds than in female buds, respectively. Overall, these results show that high levels of these genes may have promoted the differentiation of male floral buds (Figure 11b-d).

\section{Discussion}

PCD is a normal physiological process that plays an important role in growth and development. A large body of evidence has been established for animal PCD, while the molecular mechanisms of 
PCD remain to be explored in plants [30]. In this study, several microscopic methods were used to test for the occurrence of PCD during the arrest period of the stamen or carpel primordium in persimmon female or male buds, respectively. Among which, H\&E staining is a cytologically recognizable and morphological assay that can detect PCD based on cellular morphology. Decrease in the volume of the cytoplasm, shrinkage of the cytoplasm and nucleus, and DNA fragmentation are the main signs of PCD [31]. The TUNEL assay combines molecular biology with morphology to detect DNA damage in situ, which is considered to be more objective for PCD, particularly in its early stages. Dead cells are stained completely with green fluorescence, while the normal cells are blue fluorescence [19]. In addition, mitochondrial signaling pathway is important in PCD, in which cyt-c plays a pivotal role in inducing PCD and in electron transfer in the mitochondrial respiratory chain [32-34]. It has been demonstrated that maize (Zea mays) cells induced by Agrobacterium tumefaciens performed typical apoptosis-like features, such as cytochrome $\mathrm{c}$ release and DNA fragmentation [35]. Thus, IHC assay making full use of the principle of antigen and antibody for positioning and semi-quantitative research of the key enzymes, was conducted to elucidate the PCD process in inappropriate sex organs. Dead cells are stained with brown, while the normal cells are blue.

Conclusion description in results of H\&E, TUNEL, and IHC assays indicated that PCD strongly accumulated in inappropriate sex organs on April 14, 2017 during the microsporocyte and macrosporocyte period of male and female floral buds, respectively. In addition to that mentioned above, a TEM method was used to observe the features of cell death morphology more clearly, and the signs of the condensation of the cytoplasm and chromatin, engulfment of the cytoplasm by lytic vacuoles, volume changes of the cytoplasm and vacuole, as well as the nucleoli fragmentation all demonstrated the occurrence of dead cells in arrested carpel and stamen in male and female flowers collected on April 14, 2017, respectively. Our systematic morphogenetic analysis of arrest of inappropriate organs during male and female flower development was coincidental with that of Bai et al. (2004) [36]. The results provide some potentially useful information in the unisexual flower formation of persimmon.

In this present study, we found that the abortion of inappropriate sex organs at critical time points, which related to PCD, resulted in unisexual flowers. Thus, it is possible to control the sexual types of persimmon flowers by the regulation of PCD. This hypothesis was supported by a report in which the application of zebularine, a DNA demethylation agent, promoted pistil development in male flowers and induced a sexual transformation from male flowers to semihermaphroditic flowers in a D. kaki cultivar of Zenjimaru [5]. If more unisexual persimmon flowers will be transformed to hermaphroditic flowers artificially in the future, the original female flowers will become pollen donors, and the original male flowers will become pollen receptors, which will be helpful for the controlled pollination experiments.

Sufficient biological duplication, as well as necessary positive and negative controls, were used to ensure the accuracy and reliability of our results. Nonetheless, the growth of plant organs is mainly driven by the disappearance of old cells and continuous generation of new cells. As a result, there is no doubt that PCD occurs during normal growth and development in plants. For instance, a cracked anther is needed to ensure pollen transmission after flowering, during which PCD is observed in the septum parenchymal and epidermal cells adjacent to the cracks [37]. PCD also occurs in the conductive tissues around the pollen tube of the pistil during growth and development [38]. Death of part of the megaspore represents a type of PCD that occurs in seed plants and is influenced by genetic control [39]. Although PCD in inappropriate sexual organs was our research priority, it was inevitable for PCD to occur in the stamen primordium of the male flowers and the pistil primordium of the female flowers at the microsporocyte and macrosporocyte stages, as well as the comparable staining in petal primordium as stamen or carpel in our investigation according to the analysis described above.

The methylation level of $M e G I$ in polyploid persimmon determines sex differentiation of flowers, and high expression levels produce female-biased buds [5]. BAG5 is a well-known BAG family member and a stress-inducible gene. Knockdown of $B A G 5$ causes cell death, decreases cell viability, and exacerbates cleavage of PCD-related genes [22,23]. AIF is confined to the mitochondria and is proposed to be involved in 
chromatin condensation as well as the formation of large-scale DNA fragmentation [24,25]. We determined that the relative expression levels of the genes homologous to MeGI, BAG5, and AifA were consistent in female floral buds, and that all gene expression levels increased to a peak from April 5 to 14, 2017, and then declined toward the end of sampling. The levels of these genes in the male floral buds decreased or slightly increased, suggesting that the accumulation of genes homologous to MeGI, BAG5, and AifA might be part of the mechanism controlling the arrest of stamen primordium. Furthermore, considering the suggestion of Chen et al. (2009) [12] that the expression of the HSP70 gene apparently increased under high salt stress while the degree of PCD decreased, we presumed that the HSP70 gene may act as a potential regulator of PCD. Contradictory with the results described above, the gene homologous to HSP70 seemed to induce inappropriate stamen arrest, as the expression levels in the female floral buds exhibited peaks during the critical April 14, 2017 period.

According to Tanimoto et al. (2005) [40], cyt-c interacts with caspase-9 to form the apoptosome, leading to PCD in animals. Although to date no caspases have been identified in plants, metacaspases, which have the caspase domain and are involved in the regulation of PCD, are proved to be caspase-like proteins and functionally resemble animal caspases [26,41,42]. The mRNA expression levels of type II metacaspase (LeMCA1) are upregulated in Botrytis cinerea-induced PCD in Lycopersicon esculentum [43]. In another study, metacaspase in yeast was effective for activating the downstream genes that exhibit caspase activity, thereby leading to PCD under oxidative stress [44]. Our results were in accordance with reports that the gene homologous to $A M C 9$ reached its peak in male floral buds at the crucial stage of April 14, 2017, but consistently deceased among all stages in female floral buds, demonstrating that a high level of gene homologous to $A M C 9$ may be required for PCD in pistil primordium.

In animal systems, PCD is synonymous with apoptosis, which is synthesis of the morphological and biochemical features including chromatin condensation, cytoplasm shrinkage, DNA and nuclear fragmentation, and formation of apoptotic bodies [42]. Although several morphological similarities of PCD in plant cells are similar to that of animal cells, the terminology of 'apoptosis' is not justified in plants for apoptotic bodies as well as phagocytic cells are absent in plant, due to the presence of the cell wall [19,45]. Moreover, plants do not have caspases, which is one of the most critical elements identified as a molecular marker in apoptosis and cell proliferation in animals, and the closest structural homologs to animal caspases is the plant metacaspases [41]. As a result, adequate choices of analytical methods are necessary to correctly diagnose the occurrence of PCD. Additionally, we encourage the use of quantification of cell death along with necessary statistical methods to demonstrate the accuracy of the experiment.

\section{Conclusions}

This study systematically assessed the process and critical point of PCD in persimmon floral organs for the first time and analyzed the expression of genes associated with PCD. In conclusion, surprisingly large areas of dead cells in the pistil primordium of the male flowers and the stamen primordium of the female flowers synchronously reached a peak at the microsporocyte and macrosporocyte period respectively, which may explain the abortion of inappropriate sex organs, leading to unisexual flowers. Interestingly, PCD occurred along with the arrest of the inappropriate sexual organs in our investigation, which we observed in the normal flower organs along with the inappropriate sexual organs, demonstrating that PCD is a part of the floral development process in persimmon. The present study showed that high levels of the gene homologous to AMC9 during the microsporocyte period in male floral buds was positively correlated with arrest of carpel primordium. High levels of the genes homologous to MeGI, BAG5, AifA, and HSP70 that occurred during the macrosporocyte period may accelerate the arrest of stamen primordium during differentiation, leading to female unisexual flowers (Figure 12). The present research helps clarify plant sexual differentiation and provides reference for controlling the sex type of persimmon flowers artificially by regulating the occurrence of PCD with exogenous hormones or other methods. Moreover, future investigations and high-sensitivity and -specificity detection methods are needed to deeply elucidate the process of PCD, as well as the link between PCD and the candidate genes in persimmon. 


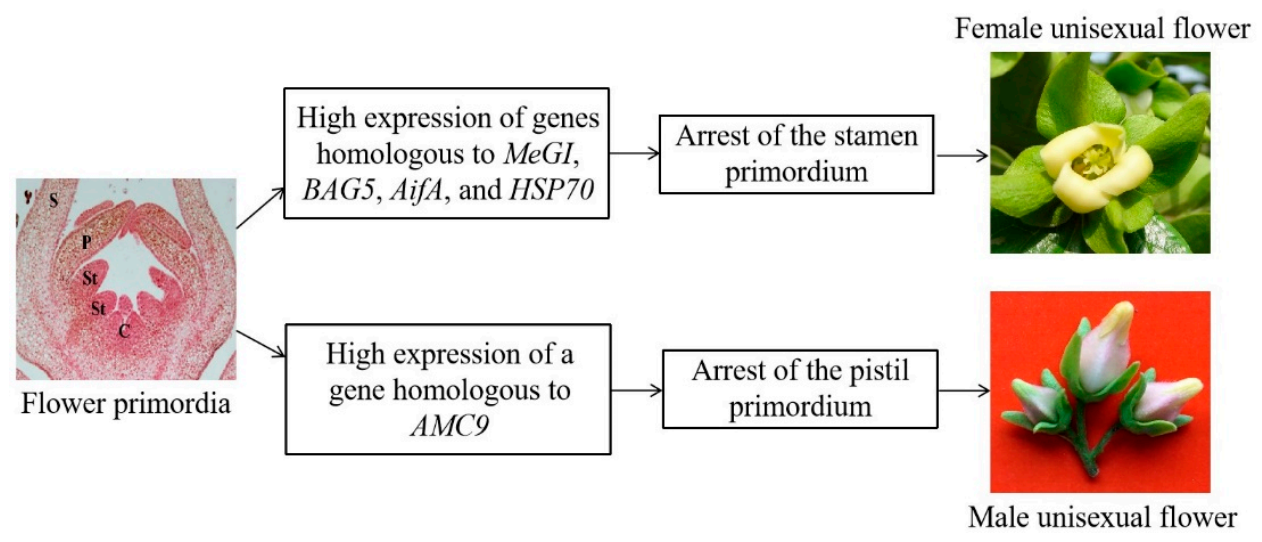

Figure 12. Putative regulatory pathways for $\mathrm{PCD}$ in female/male organ. $(\mathrm{C}=$ carpel; $\mathrm{P}=$ petal; $\mathrm{S}=$ sepal; St $=$ stamen).

Author Contributions: P.S. and J.F. conceived and designed the experiments; L.W. and H.L. carried out the experiments; L.W. and H.L. participated in the data analysis; L.W. and P.S. wrote the manuscript; Y.S., W.H., S.D., Y.M., and F.L. helped to draft and review the manuscript. All authors have read and agreed to the published version of the manuscript.

Funding: This research was supported by grants from the Fundamental Research Funds for the Central Non-profit Research Institution of CAF (CAFYBB2017ZA005) and the National Key R \& D Program of China (2018YFD1000606).

Conflicts of Interest: The authors declare no conflict of interest.

\section{References}

1. Luo, Z.R.; Wang, R.Z. Persimmon in China: Domestication and traditional utilizations of genetic resources. Adv. Hort. Sci. 2008, 22, 239-243.

2. Sun, P.; Li, J.R.; Du, G.G.; Han, W.J.; Fu, J.M.; Diao, S.F.; Suo, Y.J.; Zhang, Y.; Li, F.D. Endogenous phytohormone profiles in male and female floral buds of the persimmons (Diospyros kaki Thunb.) during development. Sci. Hortic. 2017, 218, 213-221. [CrossRef]

3. Yonemori, K.; Sugiura, A.; Tanaka, K.; Kameda, K. Floral ontogeny and sex determination in monoecious-type persimmons. J. Am. Soc. Hortic. Sci. 1993, 118, 293-297. [CrossRef]

4. Xu, L.Q.; Zhang, Q.L.; Luo, Z.R. Pollen-related characteristics of Diospyros Linn. (Ebenaceae) androecious germplasms newly found in China. Acta. Hortic. 2013, 996, 199-206. [CrossRef]

5. Akagi, T.; Henry, I.M.; Kawai, T.; Comai, L.; Tao, R. Epigenetic regulation of the sex determination gene MeGI in polyploid persimmon. Plant Cell 2016, 28, 2905-2915. [CrossRef]

6. Li, J.R.; Sun, P.; Han, W.J.; Li, F.D.; Fu, J.M.; Diao, S.F. Morphological key period study on floral sex differentiation in pollination-constant and non-astringent persimmon 'Zenjimaru'. Acta Horticulturae Sinica 2016, 43, 451-461, (In Chinese with English abstract).

7. Mohamed, A.K.; Magdy, M. Caspase 3 role and immunohistochemical expression in assessment of apoptosis as a feature of H1N1 vaccine-caused drug-induced liver injury (DILI). Electron Physician 2017, 9, 4261-4273. [CrossRef]

8. Widjiati, W.; Aulanni, A.; Hendrawan, V.F. The effect of vitrification of oocytes cumulus complex apoptosis of mice (Mus musculus) to apoptosis, rate of fertilization and embryo quality. J. Int. Med. Res. 2017, 9, 179-182. [CrossRef]

9. Zhou, H.; Li, J. Study on a new male sterile gene and apoptosis. Maize Genet. Coop. Newsl. 1997, 71, 8-9.

10. Plackett, A.R.G.; Thomas, S.G.; Wilson, Z.A.; Hedden, P. Gibberellin control of stamen development: A fertile field. Trends Plant Sci. 2011, 16, 568-578. [CrossRef]

11. Thomas, H. Senescence, ageing and death of the whole plant. New Phytol. 2003, 197, 696-711. [CrossRef] [PubMed]

12. Chen, X.; Wang, Y.; Li, J.Y.; Jiang, A.L.; Cheng, Y.W.; Zhang, W. Mitochondrial proteome during salt stress-induced programmed cell death in rice. Plant Physiol. Biochem. 2009, 47, 407-415. [CrossRef] [PubMed] 
13. Ubaidillah, M.; Safitri, F.A.; Jo, J.H.; Lee, S.K.; Hussain, A.; Mun, B.G.; Chung, I.K.; Yun, B.W.; Kim, K.M. Roles of plant hormones and anti-apoptosis genes during drought stress in rice (Oryza sativa L.). Biotech. 2016, 6, 247. [CrossRef]

14. Greenberg, J.T. Programmed cell death: A way of life for plants. Proc. Natl. Acad. Sci. USA 1996, 93, 12094-12097. [CrossRef] [PubMed]

15. Nelson, T.; Dengler, N.D. Leaf vascular pattern formation. Plant Cell 1997, 9, 1121-1135. [CrossRef] [PubMed]

16. Bleecker, A.B.; Patterson, S.E. Last exit: Senescence, abscission, and meristem arrest in Arabidopsis. Plant Cell 1997, 9, 1169-1179. [CrossRef] [PubMed]

17. Olvera-Carrillo, Y.; Van, B.M.; Van, H.T.; Fendrych, M.; Huysmans, M.; Simaskova, M.; van Durme, M.; Rivas, S.; Coll, N.S.; Coppens, F.; et al. A conserved core of PCD indicator genes discriminates developmentally and environmentally induced programmed cell death in plants. Plant Physiol. 2015, 169, 2684-2699. [CrossRef]

18. MuËller, F.; Xu, J.; Kristensen, L.; Wolters-Arts, M.; Groot, P.F.; Jansma, S.Y.; Mariani, C.; Park, S.; Rieu, I. High-temperature-induced defects in tomato (Solanum lycopersicum) anther and pollen development are associated with reduced expression of B-Class floral patterning genes. PLoS ONE 2016, 11, e0167614. [CrossRef]

19. Coimbra, S.; Torrão, L.; Abreu, I. Programmed cell death induces male sterility in Actinidia deliciosa female flowers. Plant Physiol. Biochem. 2004, 42, 537-541. [CrossRef]

20. Diggle, P.K.; Di Stilio, V.S.; Gschwend, A.R.; Golenberg, E.M.; Moore, R.C.; Russell, J.R.W.; Sinclair, J.P. Multiple developmental processes underlie sex differentiation in angiosperms. Trends Genet. 2011, 27, 368-376. [CrossRef]

21. Li, S.Z.; Du, G.G.; Wang, L.Y.; Li, H.W.; Fu, J.M.; Suo, Y.J.; Han, W.J.; Diao, S.F.; Mai, Y.N.; Li, F.D. Transcriptome sequencing and comparative analysis between male and female floral buds of the persimmon (Diospyros kaki Thunb.). Sci. Hortic. 2019, 246, 987-997. [CrossRef]

22. Guo, K.; Li, L.H.; Yin, G.; Zi, X.H.; Liu, L. Bag5 protects neuronal cells from amyloid $\beta$-induced cell death. J. Mol. Neurosci. 2015, 55, 815-820. [CrossRef] [PubMed]

23. Gupta, M.K.; Tahrir, F.G.; Knezevic, T.; White, M.K.; Gordon, J.; Cheung, J.Y.; Khalili, K.; Feldman, A.M. GRP78 interacting partner Bag5 responds to ER stress and protects cardiomyocytes from ER stress-induced apoptosis. J. Cell. Biochem. 2016, 117, 1813-1821. [CrossRef] [PubMed]

24. Savoldi, M.; Malavazi, I.; Soriani, F.M.; Capellaro, J.L.; Kitamoto, K.; Silva Ferreira, M.E.; Goldman, M.H.S.; Goldman, G.H. Farnesol induces the transcriptional accumulation of the Aspergillus nidulans apoptosis-inducing factor (AIF)-like mitochondrial oxidoreductase. Mol. Microbiol. 2008, 70, 44-59. [CrossRef]

25. Dinamarco, T.M.; Pimentel, B.C.F.; Savoldi, M.; Malavazi, I.; Soriani, F.M.; Uyemura, S.A.; Ludovico, P.; Goldman, M.H.S.; Goldman, G.H. The roles played by Aspergillus nidulans apoptosis-inducing factor (AIF)-like mitochondrial oxidoreductase (AifA) and NADH-ubiquinone oxidoreductases (NdeA-B and NdiA) in farnesol resistance. Fungal Genet. Biol. 2010, 47, 1055-1069. [CrossRef]

26. Uren, A.G.; O’Rourke, K.; Aravind, L.; Pisabarro, M.T.; Seshagiri, S.; Koonin, E.V.; Dixit, V.M. Identification of paracaspases and metacaspases: Two ancient families of caspase-like proteins, one of which plays a key role in MALT lymphoma. Mol. Cell 2000, 6, 961-967. [CrossRef]

27. Khalatbary, A.R.; Mohammadnegad, B.; Goudarzi, G. Immunohistochemical and electron microscopic study of the inhibitory effects of olive oil polyphenol on dexamethasone-induced apoptosis. Iran J. Pathol. 2017, 12, 45-52.

28. Viaene, T.; Vekemans, D.; Irish, V.F.; Geeraerts, A.; Huysmans, S.; Janssens, S.; Smets, E.; Geuten, K. Pistillata-duplications as a mode for floral diversification in (basal) asterids. Mol. Biol. Evol. 2009, 26, 2627-2645. [CrossRef]

29. Flanagan, C.A.; Hu, Y.; Ma, H. Specific expression of AGL1 MADS box gene suggests regulatory roles in gynoecium and ovule development. Plant Mol. Biol. 2010, 10, 343-353.

30. Wang, X.; Feng, H.; Zhao, S.; Xu, J.; Wu, X.; Cui, J.; Zhang, Y.; Qin, Y.; Liu, Z.; Gao, T.; et al. SPECT and PET radiopharmaceuticals for molecular imaging of apoptosis: From bench to clinic. Oncotarget 2017, 12, 20476-20495. [CrossRef]

31. Jones, A.M.; Coimbra, S.; Fath, A.; Sottomayor, M. Programmed cell death assays for plants in various methods for study of cell death in plants. Methods Cell Biol. 2001, 66, 437-451. [PubMed]

32. Ly, J.D.; Grubb, D.R.; Lawen, A. The mitochondrial membrane potential (deltapsi(m)) in apoptosis; an update. Apoptosis 2003, 8, 115-128. [CrossRef] [PubMed] 
33. Liu, D.; Zhou, H.F.; Wu, J.; Liu, W.T.; Li, Y.Q.; Shi, G.Y.; Yue, X.L.; Sun, X.W.; Zhao, Y.B.; Hu, X.W.; et al. Infection by $\mathrm{C} \times 43$ adenovirus increased chemotherapy sensitivity in human gastric cancer BGC-823 cells: Not involving in induction of cell apoptosis. Gene 2015, 574, 217-224. [CrossRef] [PubMed]

34. Song, X.F.; Tian, H.; Zhang, P.; Zhang, Z.X. Expression of cyt-c-mediated mitochondrial apoptosis-related proteins in rat renal proximal tubules during development. Nephron 2017, 135, 77-86. [CrossRef] [PubMed]

35. Heath, J.D.; Boulton, M.I.; Raineri, D.M.; Doty, S.L.; Mushegian, A.R.; Charles, T.C.; Davies, J.W.; Nester, E.W. Discrete regions of the sensor protein Vira determine the strain-specific ability of Agrobacterium to agroinfect maize. Mol. Plant-Microbe Interact. 1997, 10, 221-227. [CrossRef]

36. Bai, S.L.; Cui, J.X.; Gu, H.T.; Xu, L.Y.; Li, Y.Q.; Xu, Z.H.; Bai, S.N. Developmental analyses reveal early arrests of the spore-bearing parts of reproductive organs in unisexual flowers of cucumber (Cucumis sativus L.). Planta 2004, 220, 230-240. [CrossRef]

37. Van, D.W.G.; Woltering, E.J. Many ways to exit? Cell death categories in plants. Trends Plant Sci. 2005, 10, 117-122.

38. Su, L.J.; Jin, Y.; Lv, L.; Liu, J.X. Programmed cell death during sexual reproduction process in plants. J. Cap. Norm. Univ. 2005, 26, 69-76, (In Chinese with English abstract).

39. Bell, P.R. Megaspore abortion: A consequence of selective apoptosis. Int. J. Plant Sci. 1996, 157, 1-7. [CrossRef]

40. Tanimoto, T.; Tsuda, H.; Imazeki, N.; Ohno, Y.; Imoto, I.; Inazawa, J.; Matsubara, O. Nuclear expression of CIAP-1, an apoptosis inhibiting protein, predicts lymph node metastasis and poor patient prognosis in head and neck squamous cell carcinomas. Cancer Lett. 2005, 224, 141-151. [CrossRef]

41. Woltering, E.J.; Bent, A.; Hoeberichts, F.A. Hoeberichts. Do plant caspases exist? Plant Physiol. 2002, 130, 1764-1769. [CrossRef] [PubMed]

42. Woltering, E.J. Death proteases come alive. Trends Plant Sci. 2004, 9, 469-472. [CrossRef] [PubMed]

43. Hoeberichts, F.A.; Ten, H.A.; Woltering, E.J. A tomato metacaspase gene is upregulated during programmed cell death in Botrytis cinerea-infected leaves. Planta 2003, 217, 517-522. [CrossRef] [PubMed]

44. Watanabe, N.; Lam, E. Two Arabidopsis metacaspases AtMCP1b and AtMCP2b are arginine/lysinespecific cysteine proteases and activate apoptosis-like cell death in yeast. J. Biol. Chem. 2005, 280, 14691-14699. [CrossRef]

45. Doorn, W.G.; Beers, E.P.; Dangl, J.L.; Franklin-Tong, V.E.; Gallois, P.; Hara-Nishimura, I.; Jones, A.M.; Kawai-Yamada, M.; Lam, E.; Mundy, J.; et al. Morphological classification of plant cell deaths. Cell Death Differ. 2011, 18, 1241-1246. [CrossRef] 